\title{
Revealing the Footsteps of Apostles in the Book of Acts in the New Testament of the Bible
}

\author{
Wei Hu \\ Department of Computer Science, Houghton College, New York, USA \\ Email: wei.hu@houghton.edu \\ Received May $8^{\text {th }}, 2013$; revised June $7^{\text {th }}, 2013$; accepted July $3^{\text {rd }}, 2013$
}

\begin{abstract}
Copyright (C) 2013 Wei Hu. This is an open access article distributed under the Creative Commons Attribution License, which permits unrestricted use, distribution, and reproduction in any medium, provided the original work is properly cited.
\end{abstract}

\begin{abstract}
The book of Acts documents the apostles of Christ Jesus being empowered and guided by the Holy Spirit to bear witnesses for Him from Jews to Gentiles first in Jerusalem, then in Judea and Samaria, and finally throughout the Roman Empire. It records the establishment and growth of the early church and the spread of the good news of salvation through Jesus in spite of strong oppositions. Acts serves as a critical link that connects the gospel of Christ as seen in the four Gospels with its applications as presented in the letters of the New Testament, thereby providing a historical framework for the epistles. In this study a sequence of social networks was constructed from the interactions between the characters including Peter, James, John, Paul, Stephen, Philip, and Barnabas and their locations in Acts. A computational approach was applied to discover the community structures in these networks, which sequentially revealed the roles of chief apostles and their locations in each important period of Acts.
\end{abstract}

Keywords: Acts; Bible; Apostle; Jesus; Christ; Gospel; Church

\section{Introduction}

The book of Acts is authored by Luke, a coworker of Apostle Paul, and he also is the writer of the Gospel of Luke, suggesting that these two books form the two parts of a single work (Marshall 1980). Located between the four Gospels and the apostolic letters in the New Testament, this book serves as an indispensable bridge that connects the ministry of Jesus with the ministry of His apostles. The life and ministry of Paul presented in this book can enhance our learning of his letters in the New Testament. Furthermore, the conversion of Paul, which changed him from a zealous persecutor of the followers of Jesus to a fervent preacher of the gospel, exemplifies the saving power of God's love and grace. He was selected and called by God to spread the gospel to Gentiles and establish the church. Paul himself quoted his conversion and called frequently in his ministry as a living testimony of the life transformation that only the gospel can generate.

With a unique literary style, Acts records the beginning, development, and expansion of the early church from Jerusalem to Rome in the first century, as the result of the continuing work of the risen Christ and the Holy Spirit through the apostles (Dibelius \& Hanson 2004). Jesus commanded to His followers: you will be my witnesses in Jerusalem, and in all Judea and Samaria, and to the ends of the earth (Acts 1:8). It is interesting to observe that the ministry of Jesus moved in a kind of opposite direction: from Galilee, through Samaria and Judea, to Jerusalem where he was crucified, raised and ascended into heaven. The message of the gospel is that the forgivingness of sins is offered to men through Jesus, marking a clear transition

${ }^{*}$ We thank Houghton College for its financial support. from the Old Covenant of law as seen in the Old Testament to the New Covenant of grace as seen in the New Testament. Several public sermons and speeches on this message are scattered throughout this book, which demonstrate the primitive gospel that was proclaimed by early Christians and how it was preached to different groups of people.

As a companion of Paul, Luke explains in great detail how the good news of the life, death, and resurrection of Jesus Christ was preached by the apostles and other disciples, in particular by Peter and Paul (Wagner 2008). He traces the footsteps of the apostles from Jerusalem, to Judea and Samaria, and then to Asia Minor, Macedonia, and Greece, and finally to Rome. Following his call to bring the gospel to Gentiles, Paul and his team went on three missionary journeys, each several years in length. The first two journeys started and ended in Antioch and the third started in Antioch and ended in Jerusalem. Luke is the only Gentile writer of the whole Bible, since others are all Jews. Because of his Gentile background, he is able to address the cultural difference between Jews and Gentiles more deeply than other writers of the New Testament, especially when dealing with the issue of accepting Gentiles as members of the church.

Acts highlights the expansion of the church through the ministry of Peter and Paul under the direction of the Holy Spirit. Therefore, this book could be divided into three parts: chapters 1 - 12 chronicling the start and extension of the church among the Jews by Peter, chapters 13 - 21 describing the church planting among Gentiles by Paul, and chapters 22 - 28 presenting the journey of Paul to Rome. We can also summarize this book into three periods according to the spreading the gospel and establishing the church geographically: in Jerusalem (Acts 1 - 7), in 
Judea and Samaria (Acts 8 - 12), and to the ends of the earth (Acts 13 - 28).

In the present study, we created a sequence of social networks based on the interactions of the people such as Peter, Stephen, Philip, Barnabas, James and Paul and their locations in Acts. A computational method first proposed in (Hu 2013) was employed to identify the communities in these networks to uncover the roles played by key apostles and their locations in each critical period of Acts.

\section{Materials and Methods}

\section{Materials}

The text of the Bible used in this study was from the King James version (1611 authorized version), downloaded from http://printkjv.ifbweb.com. The book of Acts was used as data in our study.

\section{Methods}

Compared to random networks, real social networks exhibit several characteristic features such as small world, power law degree distribution, and community structures (Newman 2010). A community in a network is a group of vertices that are densely connected inside the group but sparsely outside. In this study, we made use of Walktrap, a community detection algorithm, which uses a similarity based on random walks and applies a hierarchical agglomerative clustering approach to merge the vertices iteratively into communities. The intuition of this approach is that: short random walks on a graph tend to stay in the same densely connected components corresponding to communities (Pons \& Latapy 2006).

\section{Results}

We present the communities found in a sequence of social networks from Acts. Although this book could be divided into three parts as mentioned in the introduction section, for the sake of clear presentation of the community structure in each network, we chose to divide the book into five parts: chapters $1-7$, 8 - 12, 13 - 18, 19 - 21, and 22 -28. With different colors these communities visualized the interactions of different characters and their locations, thereby rendering the footsteps of the apostles in Acts with a sequence of networks of communities in time (Figures 1-5). Additionally, to give a quick summery of the chapters in each network, the word clouds of top 50 most frequently occurred words in these chapters are displayed next to the network of the same chapters (Figures 1-5).

\section{Communities in Chapters 1 - 7}

These chapters depict the ascension of Jesus, end of the earthly ministry of Jesus, Matthias chosen to replace Judas, the holy spirit comes at Pentecost, Peter, along with John, preached to many in Jerusalem, Peter performed miracles, fellowship and community of believers, arrest of Peter and John for preaching the resurrection of the dead, arrest of the 12 Apostles, the sin of Ananias and Sapphira, the appointment of the seven, Stephen arrested, his speech to Sanhedrin, and his death by stoning.

These chapters summarize the early days of the church. Just as receiving the Law at Sinai singled the birth of the nation Israel, the Pentecost story indicated the birth of the church,
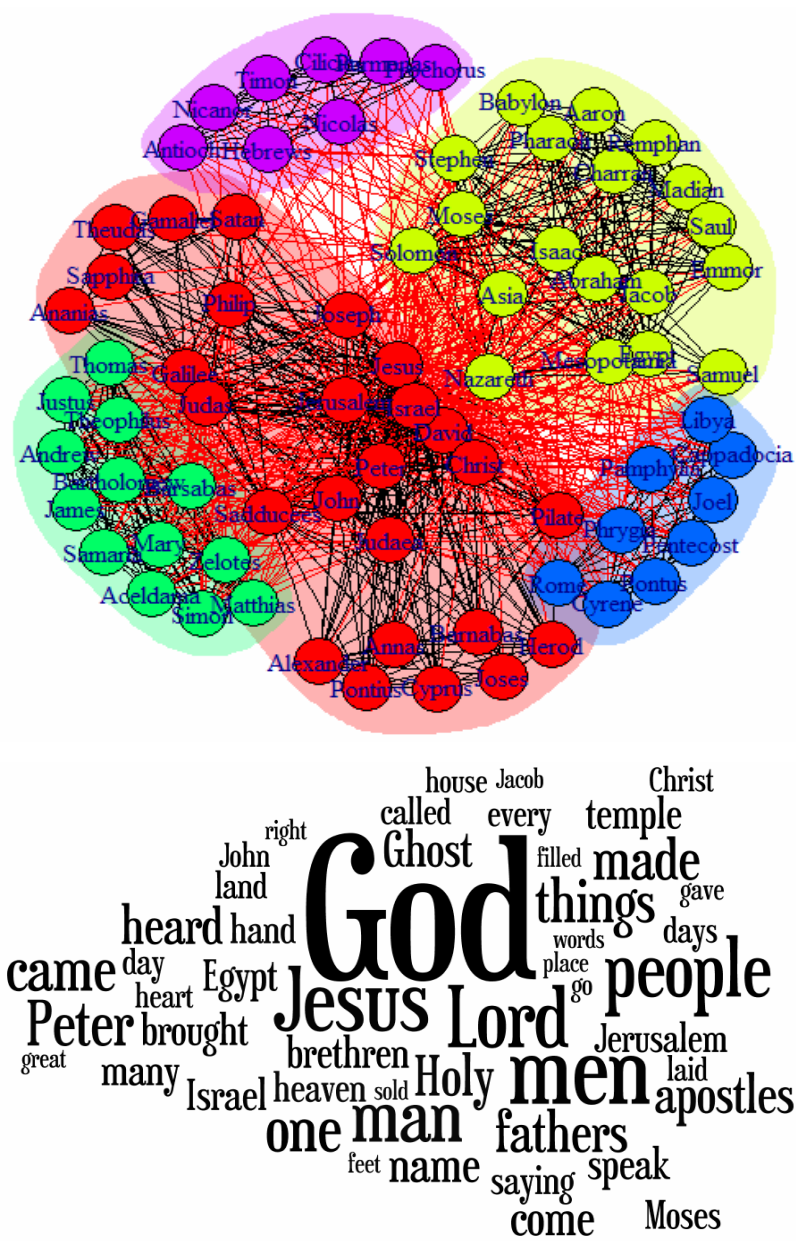

Figure 1.

Communities in the network of chapters 1 - 7 (top) and word clouds of top 50 most frequently occurred words in these chapters (bottom).

whose purpose is to bear witness for Jesus and to advance of the gospel into the entire world. The disciples were equipped with the gift of Holy Spirit for their work to preach the gospel. This small group of the faithful became witness to Christ, and they grew in number, revealing the continuing work of Jesus in His disciples. The persecution of Christians in Jerusalem caused them to scatter to other places in Judea so did the message of the gospel. Peter, John, and James were the initial leaders of this movement and became the most prominent men of the Jerusalem church.

The names of Moses, Jacob, Israel, and Egypt appeared in the word clouds in Figure 1, suggesting the history of Israel was quoted frequently to explain the gospel and how Jesus fulfilled the Old Testament scriptures during the speeches delivered by the disciples.

The network in Figure 1 showed the central figures were Jesus, Peter, John, and David, and the central locations were Jerusalem and Judaea. Stephen in yellow was a key figure in these chapters so he was a connector to a purple group.

Jesus commanded his disciples to spread the good news in Jerusalem, in Judaea and Samaria, and to the ends of the earth in chapter 1. Peter, John, David, Israel, Jerusalem, and Judaea colored red were in one group at the center of the network, and Samaria colored light green was in another group. 
The sermon of Stephen in chapter 7 addressed the well known heroes and their stories in the history of Israel using Abraham, Isaac, Jacob, Joseph, Israel in Egypt, Pharaoh, Moses, Aaron, Israel in the wilderness, Joshua, the Tabernacle of Testimony, David, and Solomon. Most of these names appeared in one community colored yellow. At the end of chapter 7, Saul of Tarsus appeared for the first time as he witnessed Stephen being stoned to death as the first Christian martyr. Stephen and Saul were in the yellow group too. In chapter 3, Peter quoted the prophets from Samuel on who foretold the coming of Christ. As a result, Samuel was in the yellow group.

In chapter 5, Ananias and his wife Sapphira died because they had lied to Peter about the money they received from selling their possessions. This couple's names were next to each other in red. Paul was educated by Gamaliel who was a prominent teacher of the Jewish law. Gamaliel was in the red group since he was cautioning his colleagues in the Sanhedrin not to make a hasty decision against the followers of Jesus in chapter 5 .

\section{Communities in Chapters 8 - 12}

These chapters document the Jerusalem church persecuted and its believers scattered, Philip preached the gospel in Samaria, he converted Simon the Sorcerer, he then converted the Ethiopian, conversion and call of Paul, Saul in Damascus and Jerusalem, Peter healed Aeneas and Dorcas, Cornelius calls for Peter, Peter's vision to preach the gospel to Gentiles, Peter preached the risen Christ at Cornelius's house, Peter explained his actions using his vision because Jews objected his association with Gentiles, the new Gentile church in Antioch, Peter's miraculous escape from prison, Herod's persecution of the church, his killing James brother of John, and he was struck by an angel and eaten by worms because he did not give praise to God. The disciples were called Christians rather than Jews for the first time at Antioch in chapter 11:25. Chapter 12 shifts the focus of this book from Peter's ministry to Paul's.

The message of gospel was taken by Phillip to Samaria, where the Samaritans began to believe in Christ. Phillip in green and Samaria in red were close to each other in the network, and Samaria appeared 5 times in these chapters so it functioned as a local connector to two other communities. Phillip was also connected to Stephen that was a local hub for the vertices in green and red.

In chapter 9, Saul went to the high priest and asked him for letters of introduction to the synagogues in Damascus. On his way from Jerusalem to Damascus to arrest followers of Jesus, suddenly a light from heaven flashed around Paul so he fell to the ground and the risen Jesus conversed with him. For three days, he was blind, and did not eat or drink anything (Acts 9:9). Jesus then explained in a vision to Ananias, a believer in Damascus, that Saul was His chosen instrument to deliver the gospel to the Gentiles, their kings, and the people of Israel. Paul realized that his persecuting the church had made himself an enemy of God, so he became the most determined of the apostles of Jesus.

Barnabas was the person who introduced Paul to the apostles in the Jerusalem church when they treated Paul like the vicious persecutor of the believers and an enemy of the church he was (Acts 9:27). As a result, a good friendship between Paul and Barnabas was formed and they departed on a missionary journey together later.
The central figures in the network in Figure 2 were Peter, Saul, John, and Barnabas, and the central locations were Jerusalem, Judaea, and Caesarea. Samaria, served as a local hub, connected to Philip in the light blue community and to a blue community.

Saul of Tarsus was connected to many important vertices such as Christ, Jesus, Jerusalem, Stephen, John, Peter, Jew, so Saul, along with Peter, John, Barnabas and Jerusalem and Judea, was in the center of this network although his prime time was in subsequent chapters.

Cornelius was a Gentile and a Roman officer in Caesarea, who was a devout man, feared God, and prayed to God continually. While he was praying, an angel appeared to him and urged him to send to Joppa for Simon called Peter. So Peter brought the gospel to Cornelius and his family, since in a vision God revealed to Peter of His plan to bring the gospel to Gen tiles. Peter was the first who welcomed the Gentiles to the church and faith in Christ. Cornelius was connected to Peter, Joppa, Simon, Jesus, Christ, Israel, and Galilee in the network.

\section{Communities in Chapters 13 - 18}

These chapters present the call for evangelism, Barnabas and
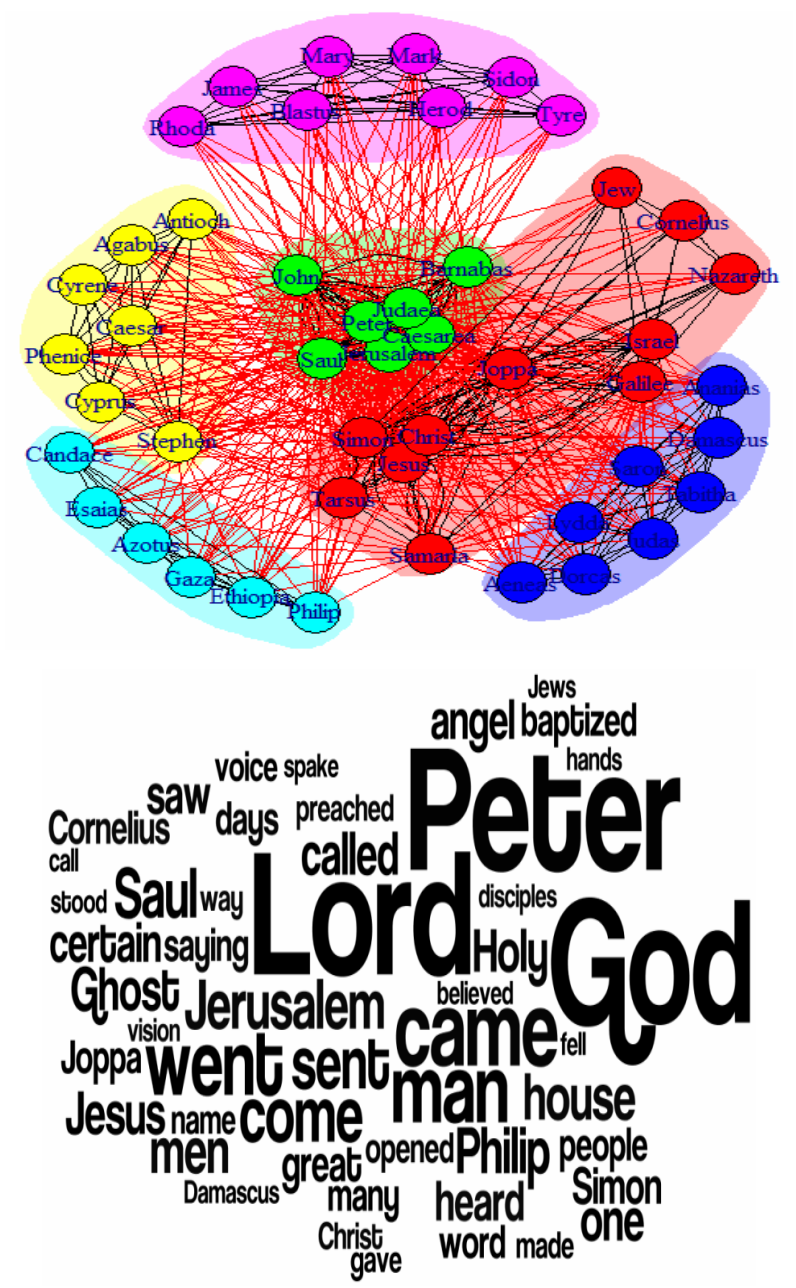

Figure 2.

Communities in the network of chapters 8 - 12 (top) and word clouds of top 50 most frequently occurred words in these chapters (bottom). 
Saul, accompanied by John Mark, departed on a mission trip, Saul and his coworkers in Cyprus, Saul now called Paul, in Pisidian Antioch, in Iconium, in Lystra and Derbe, and return to Antioch in Syria, end of their first mission trip, the council at Jerusalem and its letter to Gentile believers in Antioch, disagreement over Mark between Paul and Barnabas, Timothy (spelled as Timotheus in King James) joined Paul and Silas, Paul received vision to go to Macedonia, conversion of Lydia in Philippi, Paul and Silas in prison for delivering a girl from her demonic possession, Paul and his team in Thessalonica, in Berca, in Athens, in Corinth, return to Antioch, end of their second mission trip, Aquila and Priscilla instructed Apollos about Christ (part of their third mission trip).

The commission given by Jesus to his disciples was that the gospel be preached to all nations. At the beginning, the church was composed of only Jews, and the gospel then reached the Samaritans (mixed Jew and Gentile) and finally the Gentiles. It was at Antioch church organized mission started. Peter helped the church to recognize that the gospel was for both Jews and Gentiles. He accepted the Gentiles as members of God's people and ate with them.

Paul changed his name from Saul a Jewish name to Paul a Greek name in chapter 13:9, implying his ministry focus was on Gentiles. John left Paul's team and returned to Jerusalem in chapter 13. Hence from this chapter on, Paul remained the single essential figure of this book.

These chapters cover the first two missionary journeys of Paul. At first, their focus was on preaching in the Jewish synagogues. But many of the Jews rejected their message, so they turned their eyes to the Gentiles. He stayed at several places for considerable periods of time to build churches. During a sermon in the synagogue in Antioch, Paul recalled the history of Israel, stressed Jesus' Davidic lineage, and preached the risen Christ. He converted Jews in Thessalonica, and some envious Jews instigated a riot. The disagreement between Paul and Barnabas caused them to go in two different directions for their trip. As a result, there was on team during the first trip, but now there were two in the second trip. Also a young man named Timothy joined Paul's team, who became a faithful coworker of Paul.

The network in Figure 3 displayed that the central figures were Jesus, Paul, John, and Jew, and the central locations were Jerusalem and Antioch with Iconium in the same group connecting to three other groups as well. Judea and Samaria were no longer at the center of the network, but they were at the boundary of the network in light blue. The word clouds and network in Figure 3 both highlighted the major role of Paul and Barnabas in these chapters.

The names in Paul's first mission trip were in the green group. During his speech in Pisidian Antioch, Paul mentioned the Israel history using names in yellow like David, Saul, Cis, Jesse, Benjamin, Abraham, Egypt, and Moses. The names such as Silas, Timothy, Athens, and Corinth in his second mission trip were in the red group.

The Jews from Judaea claimed that circumcision is necessary for Christians. Between his first and second mission trips, Paul participated in a conference in Jerusalem, which determined that Gentiles who converted to Christianity needed not to follow the Jewish practice of circumcision (Chapter 15). The frequent discussions on the topic of Jew in these chapters made Jew being at the center of this network.
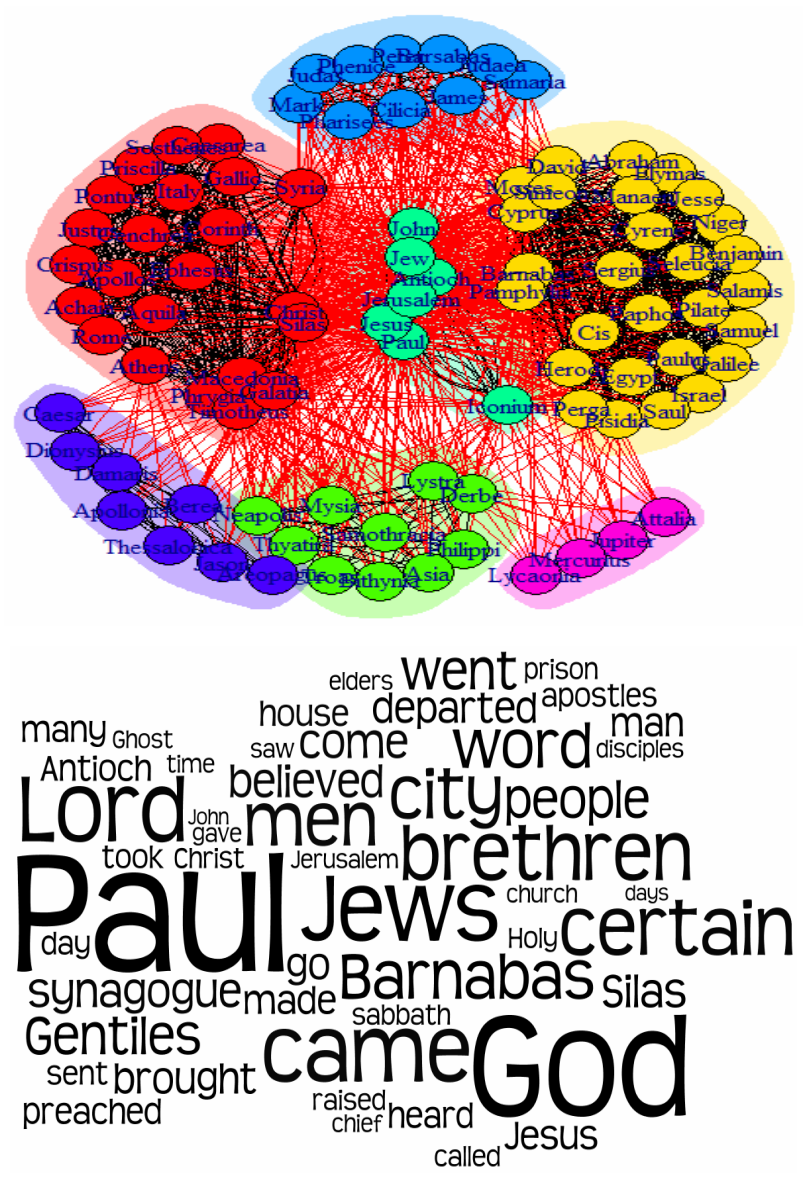

Figure 3.

Communities in the network of chapters 13 - 18 (top) and word clouds of top 50 most frequently occurred words in these chapters (bottom).

\section{Communities in Chapters 19 - 21}

These chapters detail Paul in Ephesus, the riot in Ephesus, Paul in Macedonia and Greece, Paul's farewell to the Ephesian elders, Paul and his team went to Jerusalem, end of their third mission trip, in Jerusalem Paul met with James and the elders, Jews stirred a mob against Paul, Roman soldiers rescued him, Paul spoke to the crowd.

Luke says in Acts 19:10, this went on for two years, so that all the Jews and Greeks who lived in the province of Asia heard the word of the Lord. In the Roman Empire at that time there were three major cultures, Romans, Greeks, and Jews. During his stay in Ephesus, Paul baptized 12 disciples, ministered in synagogue, and sent out his coworkers to plant churches in different cities of Asia.

The network in Figure 4 showed the central figures were Jesus, Paul, Trophimus, and Jew, and the central locations were Jerusalem and Asia with Syria being a connector to other communities. Also the word clouds in Figure 4 revealed the importance of Asia in Paul's third trip. The vertex Asia appeared in the network of chapters 13 - 18 as a non-central member. The vertex Jew was still close to the center, but not as central as it was in the previous network in Figure 3.

Several disciples accompanied Paul during this missionary trip: Sopater of Beroea, the son of Pyrrhus; and of the Thessalonians, Aristarchus and Secundus; and Gaius of Derbe, and 

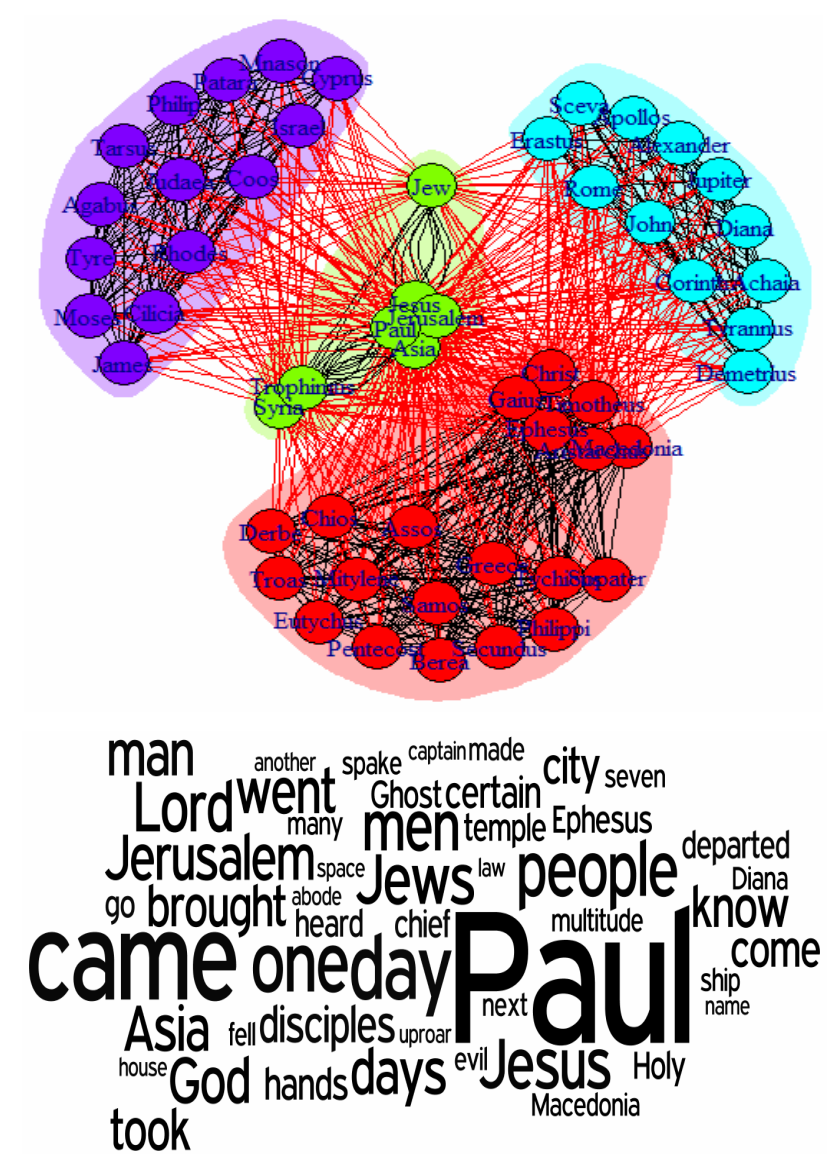

Figure 4.

Communities in the network of chapters 19 - 21 (top) and word clouds of top 50 most frequently occurred words in these chapters (bottom)

Timothy; and of Asia, Tychicus and Trophimus (Acts 20:4). Most of these names appeared in one cluster in red whereas Trophimus served as a connector to other communities.

\section{Communities in Chapters 22 - 28}

These chapters capture Paul spoke to the crowd (continued from the end of chapter 21), Paul's Roman citizenship protected him, trial of Paul before Sanhedrin in Jerusalem, Paul escorted to Caesarea, plot to kill Paul, Paul's imprisonment in Caesarea, trial of Paul before Felix the Roman governor of Judea and then before Festus the successor of Felix, Festus consulted Agrippa king of Judea, trial of Paul before Agrippa, Paul decided to appeal his case to Caesar the Roman emperor, Paul sailed for Rome, his ship encountered a storm, his ship was wrecked, Paul and his coworkers landed on Malta, their arrival in Rome, finally for two years Paul preached at Rome under house arrest, which symbolized the presence of the gospel in the capital of the world at that time.

Paul's witness in these chapters was exactly what the Lord had commanded in (Acts 9:15), Go! This man is my chosen instrument to carry my name before the Gentiles and their kings and before the people of Israel. In chapter 23, the Lord appeared to Paul and said, Take courage! As you have testified about me in Jerusalem, so you must also testify in Rome (Acts 23:11). When he appeared in court scenes, Paul, like Peter and Stephen, seized the occasion to preach the gospel fearlessly
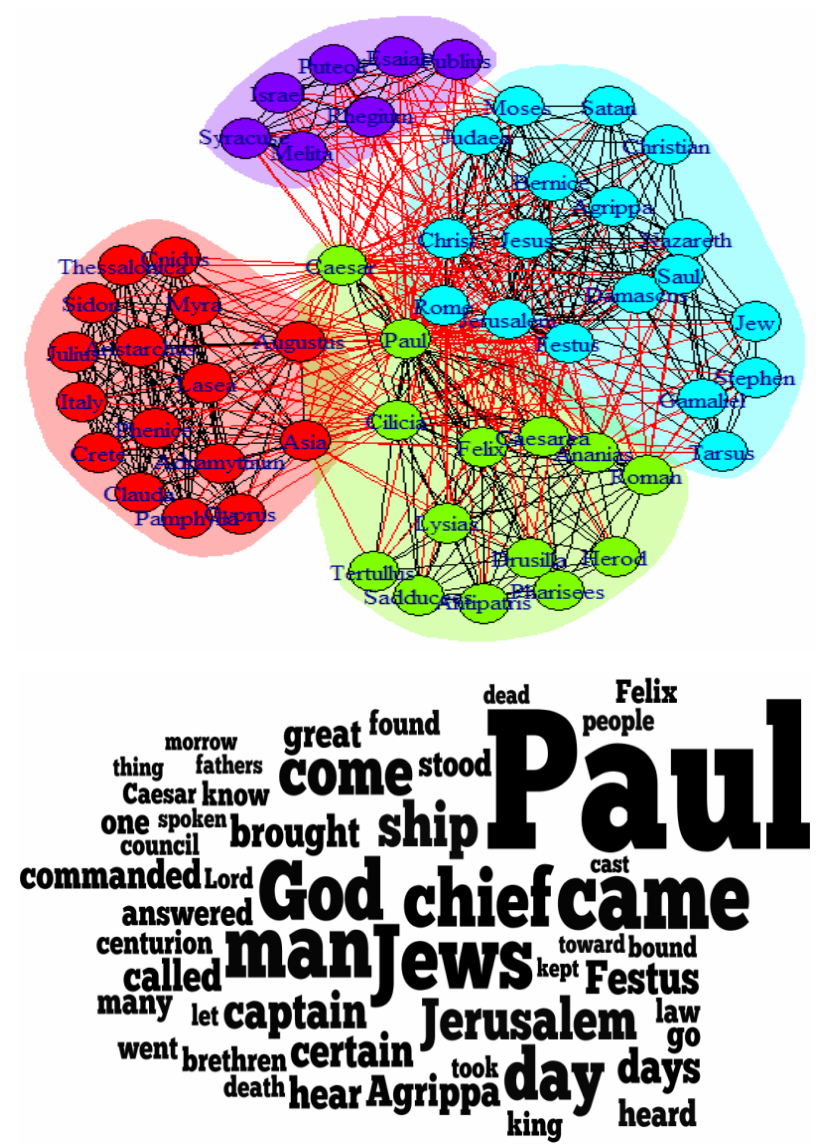

Figure 5.

Communities in the network of chapters 22 - 28 (top) and word clouds of top 50 most frequently occurred words in these chapters (bottom).

before the Jews and Roman officials. Although a prisoner, Paul evangelized on his way to Rome and in Rome, a city he had dreamed to visit for so long. It was Paul's custom to preach the good news of salvation through Jesus in every situation, every moment, and everywhere.

The network in Figure 5 showed the central figures were Paul, Caesar, and Jesus, and the central locations were Jerusa lem and Rome. Vertex Rome was present as a non central member in the network of chapters 19 - 21 in Figure 4. Further, Felix and Caesar were in green and Agrippa and Festus in blue. The red vertex Asia connects its community with a green as well as a blue community, even though it was no longer centralto the network. The name Augustus was referring to Roman Emperor Nero.

\section{Discussion and Conclusion}

The book of Acts documents the birth and growth of the early church from Jerusalem, to Judea and Samaria, and then to the rest of the Roman Empire by the followers of Jesus directed by the Holy Spirit. It traces the spread of the gospel of salvation through Jesus to all nations, from Jews to Gentiles and from ordinary people to kings, thus making the transition of Christianity from its root in Judaism to a worldwide ministry. There are several verses in Acts that report the advance of the early church (Acts 2:47; 6:7; 9:31; 12:24; 16:5; 19:20; 28:30, 31).

Acts does not exhaustively record all events, but selects cer- 
tain events to illustrate the formation of Christian faith and church. It begins with the ministry of Peter and other disciples with Jews in Jerusalem and then shifts its focus to the work of Paul with Gentiles in Antioch, Ephesus, Rome, and other parts of the Roman Empire. Amazingly, God used the persecution of the church and the rejection of the gospel to cause the efficient spread of the gospel throughout the world. It was a common pattern of Paul's ministry: he always went to the Jews first, when the gospel was rejected by them, Paul went to the Gentiles. Paul claimed when he was in Rome, this salvation of God has been sent to the Gentiles; they will listen (Acts 28:28). However, God has a timing when all Israel will be saved (Romans 11:25-27).

In this study a computational approach to study of Acts was proposed. The community structures identified from a sequence of social networks made from this book revealed the roles played by the apostles in time. Our analysis of each network demonstrated that Jesus and Jerusalem remained at the center while other central figures and their locations changed over time: from Peter and John in Jerusalem and Judea (Acts 1 - 7), to Peter, Saul, John, and Barnabas in Jerusalem, Judea, Caesarea, and Samaria (Acts 8 - 12), to Paul, Barnabas, and John in Antioch and at the council in Jerusalem (Acts 13 - 18), to Paul in Jerusalem and Asia (Acts 19 - 21), finally to Paul and Caesar in Jerusalem and Rome (Acts 22 - 28).

Many important issues encountered by Paul in Acts such as adherence to Jewish law and the relationship between Jews and Gentiles within the church were addressed in his letters to the churches. Our learning of the book of Acts can aid our understanding of these letters, which comprise almost half of the books in the New Testament.

\section{REFERENCES}

Marshall, H. (1980). Acts (the Tyndale new testament commentaries). Grand Rapids, MI: Wm. B. Eerdmans Publishing Company.

Dibelius, M., \& Hanson, K. C. (2004). The book of Acts: Form, style, and theology. Minneapolis, MN: Fortress Press.

Wagner, C. P. (2008). The book of Acts: A commentary (3rd ed.). Ventura, CA: Regal.

$\mathrm{Hu}, \mathrm{W}$. (2013). Communities inferred from the books of Samuel in the Old Testament of the Bible. Advances in Historical Studies, 2, 70-80. Newman, M. (2010). Networks: An introduction. USA: Oxford University Press.

Pons, P., \& Latapy, M. (2006). Computing communities in large networks using random walks. Journal of Graph Algorithms and Applications, 10, 191-218. doi:10.7155/jgaa.00124 